\title{
Evaluation of parental awareness of children's obesity-related health risk in Poland: survey study
}

Ocena świadomości rodziców na temat ryzyka zdrowotnego związanego z otyłością u dzieci w Polsce - badanie ankietowe

\author{
Aleksandra Okapiec, Anna Wołoszyn-Durkiewicz, Maciej Ledwosiński, Marta Dudzic, \\ Małgorzata Myśliwiec
}

Department and Clinic of Paediatrics, Diabetology, and Endocrinology, Medical University of Gdansk, Poland

\begin{abstract}
Introduction: Childhood obesity is a complex problem that requires a multidimensional approach. The constantly increasing prevalence of childhood obesity should be of interest not only to pediatricians but also government bodies. Parental awareness of how excess body weight influences a child's health is one of the aspects that should be considered.

The aim of the study: Our main goal was to assess the awareness and opinions on possible adverse effects of excess body weight of parents of children attending several primary schools in the Pomeranian, Lubelskie and Świętokrzyskie Voivodships in Poland.

Material and methods: The questionnaire-based survey was conducted in 2019 during parent-teacher meetings in public schools in the Pomeranian, Lubelskie and Świętokrzyskie Voivodeships Statistical analysis was then performed on the 277 received questionnaires using Statistica 13.3 software package and spreadsheet editor Microsoft Excel 2018.

Results: Inhabitants of urban areas perceived a stronger link between obesity and its influence on health. Similar results were observed in the group consisting of parents with higher education. Gender had no significant effect on the opinion concerning complications of obesity.

Conclusions: Overall, most of the parents recognized the influence of obesity on health. The degree of awareness among respondents was the weakest in relation to the influence of obesity and diet on carcinogenesis.

Key words:

childhood obesity, adolescent obesity, parents, awareness, risk perception.

\section{Streszczenie}

Wprowadzenie: Otyłość u dzieci jest złożonym problemem, który wymaga wielowymiarowego podejścia. Stale rosnąca częstość występowania otyłości wśród dzieci powinna zainteresować nie tylko pediatrów, lecz także organy rządowe. Świadomość rodziców, w jaki sposób nadmierna masa ciała wpływa na zdrowie dziecka, jest jednym z aspektów, które należy wziąć pod uwagę.

Cel pracy: Naszym głównym celem była ocena świadomości i opinii na temat możliwych negatywnych skutków nadmiernej masy ciała rodziców dzieci uczęszczających do kilku szkół podstawowych w województwach pomorskim, lubelskim i świętokrzyskim w Polsce. Materiały i metody: Badanie ankietowe przeprowadzono w 2019 r. podczas zebrań z rodzicami w szkołach publicznych w województwach pomorskim, lubelskim i świętokrzyskim. Następnie przeprowadzono analizę statystyczną 277 otrzymanych kwestionariuszy przy użyciu pakietu oprogramowania Statistica 13.3 i edytora arkuszy kalkulacyjnych Microsoft Excel 2018.

Wyniki: Mieszkańcy obszarów miejskich dostrzegli silniejszy związek między otyłością i jej wpływem na zdrowie. Podobne wyniki zaobserwowano w grupie rodziców z wyższym wykształceniem. Płeć nie miała istotnego wpływu na opinię dotyczącą powikłań otyłości.
\end{abstract}

Wnioski: Większość rodziców dostrzegła wpływ otyłości na zdrowie. Poziom świadomości wśród respondentów był najsłabszy w odniesieniu do wpływu otyłości i diety na kancerogenezę.

\section{Słowa kluczowe:}

otyłość u dzieci, otyłość wieku młodzieńczego, rodzice, świadomość, postrzeganie ryzyka. 


\section{Introduction}

Childhood overweight and obesity are known to have significant impact on both physical and mental health. Complications of increased body weight may start as soon as early childhood (eg. impaired glucose tolerance), but can also have long-term effects like increased risk of neoplasms, cardiovascular diseases diabetes mellitus and metabolic syndrome.

\section{Obesity and carcinogenesis}

Although the influence of excess body fat on carcinogenesis is not fully understood, there are few possible pathways explaining the phenomenon. Obese people present an elevated level of pro-inflammatory cytokines (TNF- $\alpha, I L-1, I L-6)$ what results in the formation of highly reactive ROS (Reactive oxygen species) that modify DNA. This mutagenic lesion in the DNA results in the production of oxidized guanine bases (e.g., 8-oxo-dG) [1] that interfere with replication leading to base substitution events. Those mutations are frequently observed in the RAS oncogene and the p53 tumor suppressor gene [2]. Some molecular mechanisms are linked with a particular type of neoplasm. To give an example insulin/IGF-1 axis is associated with pancreatic, colorectal and prostate cancers [3]. Adipose tissue as an active endocrine organ produces many hormones including leptin which promotes tumor growth and metastasis in breast cancer through estrogen receptor alpha upregulation [4].

\section{Cardiovascular diseases}

Childhood obesity is correlated with dyslipidemia (high triglycerides, low HDL serum levels) and high systolic and diastolic blood pressure in adulthood [5]. The prevalence of metabolic syndrome among adults who were obese in their childhood is increased up to $27.2 \%$ in comparison to adults with healthy weight status in childhood. Another factor which increases the risk of cardiovascular diseases is high CRP (C-reactive protein) serum level. This acute-phase protein contributes to atherosclerosis progression by modulating the immune response, activating the complement system and promoting thrombus formation and vascular remodeling [6]. Studies show the positive correlation between high BMI and CRP level in children from Caucasian and non-Caucasian background. Moreover, for every 1 kilogramme weight loss, the mean decline in CRP serum level is $-0.13 \mathrm{mg} / \mathrm{l}$ [7].

\section{Obesity in adulthood}

Obese children are approximately five times more likely to stay obese during adulthood. Half of obese children will still be obese in adolescence. Furthermore, the ratio of persisted obesity from adolescence to adulthood is much higher. It is estimated that around $80 \%$ of obese adolescents will still be obese in adulthood [8]. The risk for adult obesity increases with BMI and age of the obese or overweight child [9].

\section{Psychological aspect}

Childhood obesity correlates with psychosocial disorders such as internalizing disorders (anxiety, depression) and externalizing disorders (attention deficit hyperactivity disorder). Children with obesity also struggle with sleep problems such as obstructive sleep apnea and other sleep disruptions that not only cause daytime somnolence and concentration difficulties, but also complications such as hypertension [10]. Studies show a disproportion between genders in relation to obesity-related risk behavior. Substance abuse (smoking tobacco, drinking alcohol, cannabis use) is significantly higher among obese girls whereas obese boys were more likely to be victims of bullying [11].

\section{Type 2 diabetes mellitus}

For the last 30 years type 2 diabetes mellitus (T2DM) incidence among children has increased from less than $2 \%$ of all of the cases of diabetes mellitus among children to the current 25-45\% (the incidence rate varies among different ethnic groups and countries) [12]. The progression of impaired glucose tolerance to T2DM occurs considerably faster in adolescents than in adults. Moreover, there is a weaker response to metformin treatment among children with DMT2 than adults. Adolescents with similar body fat percentage as adults have higher fasting insulin concentration and HOMA-IR, lower hepatic and peripheral insulin sensitivity compared with adults [13].

\section{Other obesity health related diseases}

The state of low-grade inflammation that is associated with obesity causes not only diabetes, cardiovascular diseases and dyslipidemia, but also liver damage [14]. Non-alcoholic fatty liver disease (NAFLD) is the most common hepatic dysfunction among obese children. It is accounted that $55 \%$ of children with obesity have NAFLD. Some findings show that up to $11 \%$ of overweight and obese children have advanced hepatic fibrosis [15]. Moreover, in the United States NAFLD is becoming a leading cause for hepatic transplantation [16]. There is also a strong link between obesity and thyroid function. However, in some cases, hypothyroidism results in increased body weight, but most of obese children will develop subclinical hypothyroidism due to obesity itself [17]. Another obesity-related disease is the polycystic ovarian syndrome that causes hyperandrogenism, insulin resistance and metabolic syndrome. Pathological hyperinsulinemia in obese young children may interfere with the hypothalamic-pituitary-ovarian axis resulting in the full expression of PCOS in adolescent girls [18].

The immune system is another aspect that is influenced by obesity. Obese children present a two times higher risk for asthma and severe asthma phenotypes in comparison to normalweight children [19]. Some studies show solid evidence indicating that there is a higher prevalence of autoimmune diseases like rheumatoid arthritis, multiple sclerosis and psoriasis [20]. It is suspected that the imbalance of macrophage phenotypes, vitamin $\mathrm{D}$ deficiency and the increased levels of leptin are the underlying mechanisms of those autoimmune diseases [21].

\section{Aim of the study}

The aim of the study was to collect parents' opinions regarding the impact of obesity and diet on health, the risk of cancer and 
Table I. Demographic characteristics of respondents $(n=245)$

\begin{tabular}{|c|c|c|}
\hline Characteristic & $\begin{array}{l}\text { Number of } \\
\text { respondents }\end{array}$ & $\%$ \\
\hline \multicolumn{3}{|l|}{ Gender of parent } \\
\hline Man & 36 & 15 \\
\hline Woman & 209 & 85 \\
\hline \multicolumn{3}{|l|}{ Parent's education } \\
\hline Non & 0 & 0 \\
\hline Primary & 2 & 1 \\
\hline Vocational & 30 & 12 \\
\hline High school & 72 & 29 \\
\hline Higher & 141 & 58 \\
\hline \multicolumn{3}{|l|}{ Age of parent } \\
\hline $20-30$ & 10 & 4 \\
\hline $31-40$ & 122 & 50 \\
\hline $41-50$ & 100 & 41 \\
\hline$>50$ & 12 & 5 \\
\hline \multicolumn{3}{|l|}{ Area of residence } \\
\hline Urban & 162 & 66 \\
\hline Rural & 83 & 34 \\
\hline \multicolumn{3}{|c|}{ Having children over 18 years } \\
\hline Yes & 77 & 31 \\
\hline No & 168 & 69 \\
\hline
\end{tabular}

diabetes mellitus. We also wanted to evaluate parents' awareness of the risk of childhood obesity persistence into adulthood and the influence of a child's diet on their future eating habits.

\section{Material and methods}

A questionnaire-based survey was conducted between June 2019 and January 2020 among parents of children studying in public primary schools in Pomeranian, Lubelskie and Świętokrzyskie voivodeships. The number of parents who filled in the questionnaires was 277. However, 32 surveys were excluded due to the lack of demographic information. Therefore, a total of 245 questionnaires were included in the study.

We developed the questions for the survey primarily based on literature studies concerning obesity effects on health. The questionnaire was reviewed and pilot-tested by parents and healthcare professionals. The pilot tests led to minor changes and no questions were subsequently added or deleted. The self-administered anonymous survey questionnaire was divided into two sections. The first section included participant's demographic information such as age, gender and education status. The second section included 11 questions about the parent's belief in the influence of childhood obesity and children's eating habits on the health, risk of cancer, diabetes, adulthood obesity. A scale of 5 options was used to answer each question. The responders were also asked whether they have children above 18 years old. Surveys were divided according to the residency of parents (city with district rights or rural areas). Demographic information is presented in Table I.

Statistical analysis was performed using the statistical package STATISTICA 13.3 and spreadsheet editor Microsoft Excel 2018. The Student's $t$-test and ANOVA test were used to compare the responses between different demographic groups. $P$ values of less than 0.05 were regarded as statistically significant.

\section{Results}

Influence of obesity and diet on health

Overall, the majority of the parents reported that diet (72\%) considerably influences children's health. 60\% of responders strongly agreed with the statement that a child's weight affects its health (Table II). However, most of the responders from rural areas reported that they rather agree with the statement concerning the influence of a child's diet on health, as opposed to parents from urban areas who generally recognised a strong correlation between weight and health $(p<0.05)$ (Fig. 1). The difference in opinion was noticeable when taking the educational status of the parents into consideration - higher educational level was correlated with greater awareness of body mass (Fig. 2) and diet (Fig. 3) effects on health $(p<0.05)$.

\section{Influence of obesity and diet on cancer risk}

$34 \%$ of parents claimed that they strongly agree with the statement that excess body mass impacts carcinogenesis and $8 \%$ disagreed (somewhat disagree - $7 \%$, strongly disagree - $1 \%$ ) with that statement (Table II). Although inhabitants of cities reported a stronger correlation between the diet and cancer risk (Fig. 1; $p<0.05$ ), the majority of parents (regardless of their residency) did not indicate a stronger correlation between obesity and carcinogenesis (Fig. 1; $p<0.05$; Table II). Another group of responders that saw obesity as an important factor in carcinogenesis were parents who did not have children over 18 years $(p<0.05)$.

\section{Influence of obesity and diet on diabetes mellitus}

As shown in Table II, the majority of responders agreed with the statement regarding the influence of diet on diabetes development (58\%). Contrary to this, considerably fewer parents (45\%) reported that obesity is definitely a diabetogenic factor. Figure 3 shows a positive correlation between parents' educational status and their awareness of the influence of diet on 
Table II. Parental opinion $(n=245)$

\begin{tabular}{|c|c|c|c|c|c|c|c|c|c|c|c|}
\hline \multirow[t]{2}{*}{ Characteristic } & \multirow{2}{*}{$\begin{array}{l}\text { The most } \\
\text { common } \\
\text { answer }\end{array}$} & \multicolumn{2}{|c|}{$\begin{array}{l}\text { Strongly } \\
\text { agree }\end{array}$} & \multicolumn{2}{|c|}{$\begin{array}{l}\text { Somewhat } \\
\text { agree }\end{array}$} & \multicolumn{2}{|c|}{ Neutral } & \multicolumn{2}{|c|}{$\begin{array}{l}\text { Somewhat } \\
\text { disagree }\end{array}$} & \multicolumn{2}{|c|}{$\begin{array}{l}\text { Strongly } \\
\text { disagree }\end{array}$} \\
\hline & & $n$ & $\%$ & $n$ & $\%$ & $n$ & $\%$ & $n$ & $\%$ & $n$ & $\%$ \\
\hline $\begin{array}{l}\text { A child's weight affects his or her } \\
\text { health }\end{array}$ & $\begin{array}{l}\text { Strongly } \\
\text { agree }\end{array}$ & 147 & 60 & 81 & 33 & 7 & 3 & 4 & 2 & 6 & 2 \\
\hline A child's diet affects his or her health & $\begin{array}{l}\text { Strongly } \\
\text { agree }\end{array}$ & 174 & 72 & 59 & 24 & 4 & 2 & 2 & 1 & 4 & 2 \\
\hline $\begin{array}{l}\text { A child with obesity has a higher risk } \\
\text { of developing a cancer }\end{array}$ & $\begin{array}{l}\text { Somewhat } \\
\text { agree }\end{array}$ & 83 & 34 & 100 & 41 & 41 & 17 & 18 & 7 & 2 & 1 \\
\hline A child's diet influences cancer risk & $\begin{array}{l}\text { Somewhat } \\
\text { agree }\end{array}$ & 91 & 38 & 95 & 39 & 31 & 13 & 20 & 8 & 5 & 2 \\
\hline $\begin{array}{l}\text { A child with obesity has a higher risk } \\
\text { of developing diabetes in adulthood }\end{array}$ & $\begin{array}{l}\text { Somewhat } \\
\text { agree }\end{array}$ & 109 & 45 & 111 & 46 & 13 & 5 & 6 & 2 & 4 & 2 \\
\hline $\begin{array}{l}\text { A child's diet affects his or her risk } \\
\text { for developing diabetes }\end{array}$ & $\begin{array}{l}\text { Strongly } \\
\text { agree }\end{array}$ & 141 & 58 & 84 & 34 & 7 & 3 & 6 & 2 & 7 & 3 \\
\hline $\begin{array}{l}\text { A child who is overweight will also } \\
\text { struggle with excess body mass } \\
\text { in future }\end{array}$ & $\begin{array}{l}\text { Somewhat } \\
\text { agree }\end{array}$ & 109 & 45 & 112 & 46 & 12 & 5 & 9 & 4 & 2 & 1 \\
\hline $\begin{array}{l}\text { There is no correlation between } \\
\text { a child's diet and his or her eating } \\
\text { habits in adulthood }\end{array}$ & $\begin{array}{l}\text { Strongly } \\
\text { agree }\end{array}$ & 19 & 8 & 48 & 20 & 21 & 9 & 65 & 27 & 91 & 37 \\
\hline $\begin{array}{l}\text { A child physical activity will influence } \\
\text { his or her health in adulthood }\end{array}$ & $\begin{array}{l}\text { Strongly } \\
\text { agree }\end{array}$ & 185 & 76 & 49 & 20 & 1 & 0 & 4 & 2 & 6 & 2 \\
\hline $\begin{array}{l}\text { Appearance is an important aspect } \\
\text { of childhood obesity }\end{array}$ & $\begin{array}{l}\text { Strongly } \\
\text { agree }\end{array}$ & 123 & 50 & 85 & 35 & 18 & 7 & 13 & 5 & 5 & 2 \\
\hline
\end{tabular}

diabetes development $(p<0.05)$. Also, depending on residency, the knowledge about diabetogenic factors differed. Responders from rural areas as opposed to city inhabitants saw a weaker correlation between diabetes development and obesity (Fig. 1).

\section{Appearance as an aspect of childhood obesity}

Over half of the responders indicated that appearance is a highly important aspect of obesity. More parents perceived the relation between appearance and obesity than the relation between obesity and diabetes (44.67\%) or cancer $(34.02 \%)$. Residences of the rural areas mostly responded that they somewhat agree with the statement that appearance is an important aspect of obesity, as opposed to city residents who in the majority definitely agreed with that statement (Fig. 1; $p<0.05$ ).

\section{Physical activity}

As is shown in Table II, the majority of respondents (76\%) agreed that a child's physical activity will affect its future health.
With regards to this statement, there were no significant differences between different demographic groups.

Probability of persistence of child's obesity into adulthood

Almost the same number of parents chose "strongly agree" $(45 \%)$ or "somewhat agree" (46\%) options concerning the statement that obese children are more likely to be obese in adulthood (Table II). With reference to educational status there was a different pattern of responses. Parents with higher education, as opposed to those with vocational or high school education, were more aware of the higher prevalence of obesity among adults who were obese in childhood ( $p<0.05 \%$ ).

Persistence of eating habits

Overall, the majority of parents were aware of the persistence of eating habits from childhood into adulthood. However, $28 \%$ of parents claimed that a child's diet will not influence its future eating habits. 


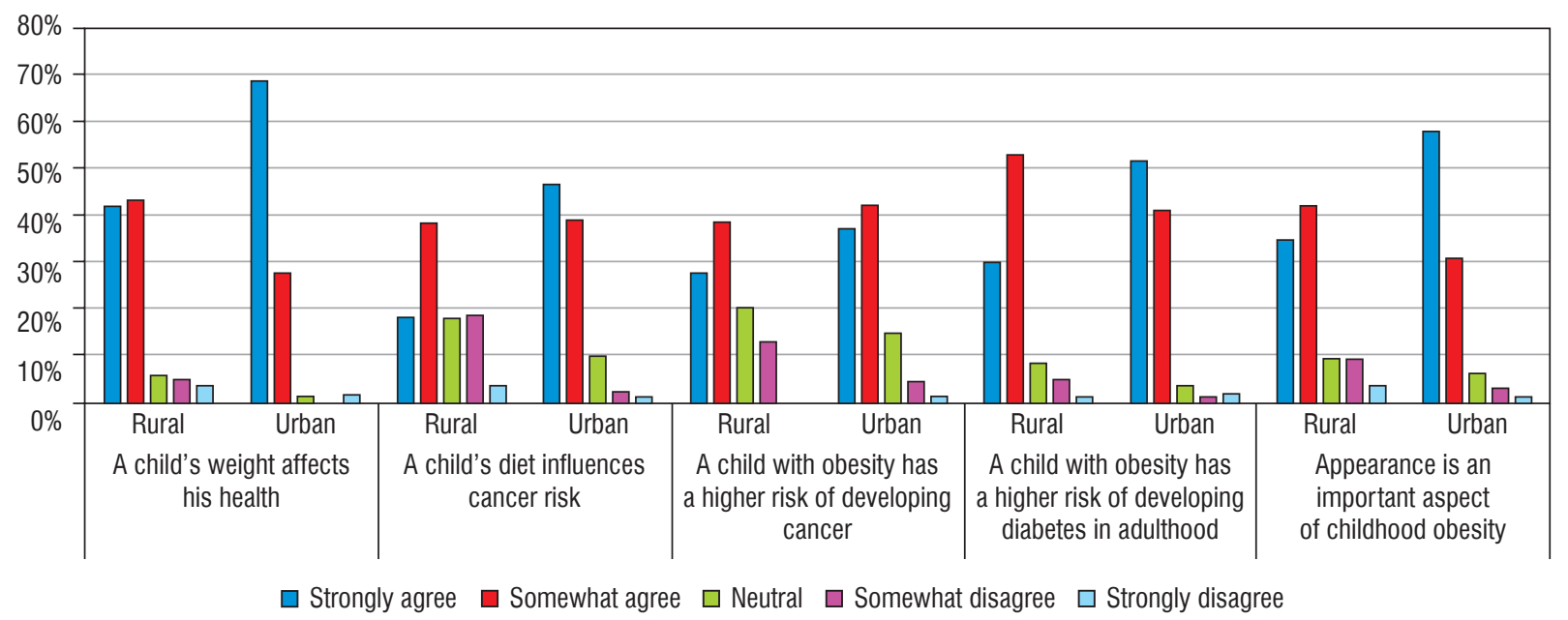

Figure 1. Comparison of parents' opinions on health-related statements between the rural $(n=83)$ and urban $(n=162)$ population

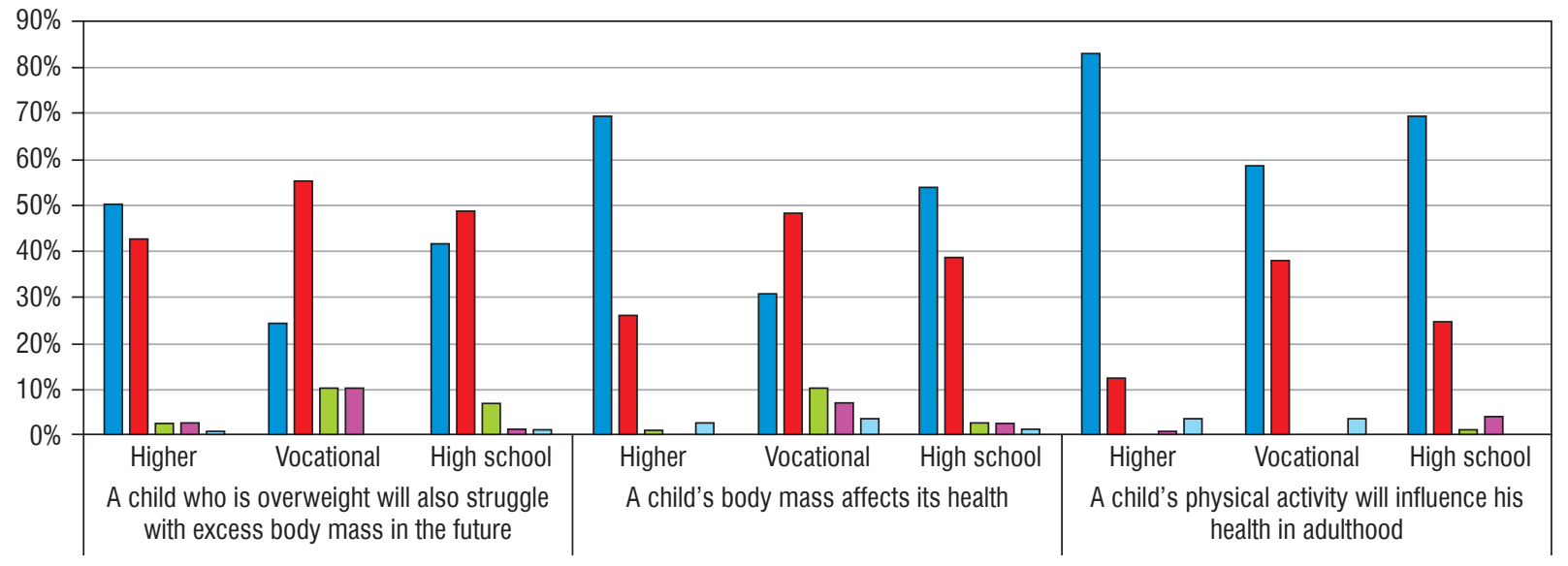

$\square$ Strongly agree $\quad \square$ Somewhat agree $\quad \square$ Neutral $\quad \square$ Somewhat disagree $\square$ Strongly disagree

Figure 2. Comparison of parents' opinions on health-related statements between parents with higher education ( $n=141)$, vocational education $(n=30)$ and high school education $(n=72)$

\section{Discussion}

The present study sought to evaluate parental awareness of the negative influence of obesity on children's health.

Our study shows that parents, in general, do appreciate the health risks of childhood obesity, as indicated by the manner in which respondents mostly agreed with the statements related to obesity. Contrary to our findings, the results obtained in a similar survey study that was conducted in Germany were quite different. Less than $50 \%$ of mothers were aware of the fact that a child's body mass above the $90^{\text {th }}$ percentile was associated with obesity related health risk [22]. In our study group over $60 \%$ of participants strongly agreed and around $30 \%$ somewhat agreed with the statement that obesity is a health risk factor. Data from the USA shows that most of the parents were concerned with the influence of obesity on children's health. The opinion did not differ between parents having obese children and healthy weight children [23]. Other research from the USA shows that parents of obese children estimated future disease risk for their children (hypertension, heart disease, depression) to be higher by $5.01-6.04 \%$ compared to parents of healthy weight children. However, reporters' opinions regarding the probability that their children would develop diabetes did not differ regardless of the weight of their children [24]. In contrast to this, the majority of the responders from our study group strongly agreed (45\%) and somewhat agreed (46\%) with the statement that obesity is a diabetogenic factor. In another survey study over $70 \%$ of parents reported diabetes as a childhood obesity related disease, $41 \%$ indicated heart disease and 29\% indicated hypertension. Definitely less parents recognized respiratory diseases, dyslipidemia 


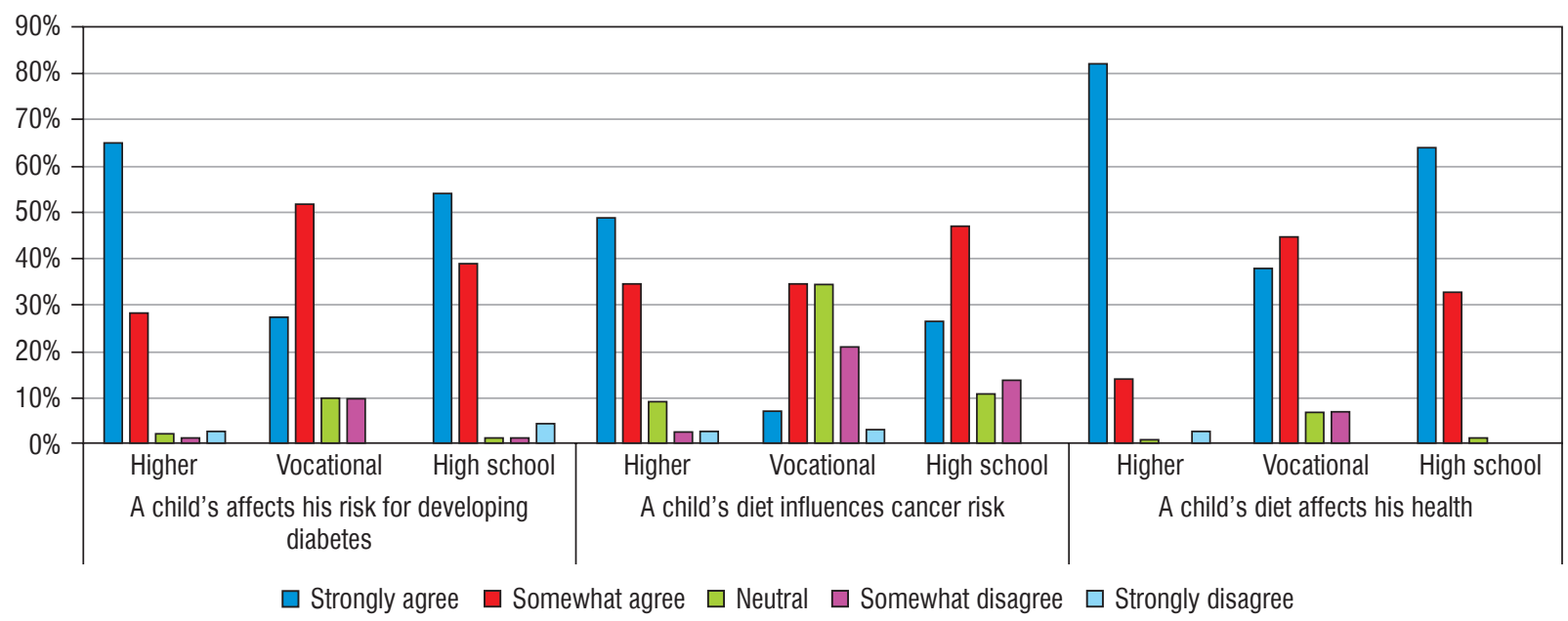

Figure 3. Comparison of parents' opinions on health-related statements between parents with higher education $(n=141)$, vocational education $(n=30)$ and high school education $(n=72)$

and depression as obesity related diseases (12-17\%) [25]. With regards to parental awareness of persistence of obesity from childhood into adulthood, responders mostly agreed with the statement that there is a higher prevalence of obesity among adults who were obese in their childhood (45\% - strongly agree, $46 \%$ - somewhat agree). Those findings corroborate the study from Australia which shows that parents of overweight children are more concerned about their children's future weight (in adolescence and adulthood) compared to parents of healthy weight children [26]

A significant difference in the results and the limited amount of studies covering the topic of parental awareness of obesity related health risk, shows how important further studies on this subject are. Moreover, there was no previous research examining the parental awareness of the influence of obesity on carcinogenesis. What is worrisome is that, according to our findings, parent's awareness of this correlation was low. Only $30.04 \%$ of responders strongly agreed with the statement that obesity increases cancer risk. Future studies on this topic could incorporate more questions related to specific diseases, responders' opinion could be evaluated depending on the weight status of their child and it should be assessed whether parents are able to define obesity.

\section{Conclusions}

Overall, most of the parents recognized the influence of obesity on health. The degree of awareness among respondents was the weakest in relation to the influence of obesity and diet on carcinogenesis. Awareness of respondents varied between urban areas and rural areas, as well as between dif- ferent education levels. Therefore, programs aiming to educate parents about the negative impact of excessive body mass on health should be introduced. The responsibility to control a child's diet lays not only with their parents, but also with physicians and governmental bodies [27].

Some scientists discuss the role of parental education in childhood obesity prevention. Robinson et al. claim that parental awareness of childhood obesity may not necessarily bring a good outcome. Their research shows that parental recognition of child overweight is correlated with increased child weight gain and impaired mental status [28]. Nevertheless, other authors show a different point of view. Drewa et al. analyzed methods of prevention of childhood obesity applied in various European countries and the result shows that Greece as a country with a high incidence of childhood obesity does not introduce many preventive measures to fight this problem. On the contrary, the Netherlands as a country with one of the lowest rates of childhood obesity in Europe emphasizes the importance of initiatives and projects to fight and educate about the childhood obesity problem [29]. Review study presented by Woods et al. highlight the importance of further study concerning the influence of parental knowledge of child weight status on potential health risk since correlation is not clear [30].

Childhood obesity is a strong predictor of adulthood obesity which has serious economic and social consequences, both for the individual and society. In Poland it is estimated that up to $2.8 \%$ of gross domestic product is spent on obesity treatment and obesity related diseases [31]. It is important to emphasize the negative psychosocial effect of obesity prevalence in next generations. By addressing the problem of overweight and obesity in children and adolescents, we are preventing the circle of obesity to continue in following generations. 


\section{References}

1. Cerdá C, Sánchez C, Climent B, et al. Oxidative stress and inflammation in non-communicable diseases - molecular mechanisms and perspectives in therapeutics. 2014; 824: 5-17. doi: 10.1007/ 978-3-319-07320-0

2. Kompella P, Vasquez KM. Obesity and cancer: A Mechanistic Overview of Metabolic Changes in Obesity That Impact Genetic Instability. Mol Carcinog 2019; 58: 1531-1550. doi: 10.1002/mc.23048.

3. Ungefroren $\mathrm{H}$, Gieseler F, Fliedner $\mathrm{S}$, et al. Obesity and Cancer. Horm Mol Biol Clin Investig 2015; 21: 5-15. doi: 10.1515/hmbci-2014-0046

4. Sabol RA, Beighley A, Giacomelli P, et al. Obesity-altered Adipose Stem Cells Promote ER + Breast Cancer Metastasis Through Estrogen Independent Pathways. Int J Mol Sci 2019; 20: 1-14. doi: 10.3390/ijms20061419

5. Nadeau KJ, Maahs DM, Daniels SR, et al. Childhood Obesity and Cardiovascular Disease: Links and prevention strategies. Nat Rev Cardiol 2011; 8: 513-525. doi: 10.1038/nrcardio.2011.86

6. Stancel N, Chen C, Ke L, et al. Reviews Interplay Between CRP, Atherogenic LDL, and LOX-1 and Its Potential Role in the Pathogenesis of Atherosclerosis. Clin Chem 2016; 62: 320-327. doi: 10.1373/clinchem.2015.243923.

7. Tam C, Clément K, Baur L, et al. Obesity and Low-Grade Inflammation: A Paediatric perspective. Obes Rev 2010; 11: 118-126. doi: 10.1111/j.1467-789X.2009.00674.x.

8. Simmonds M, Llewellyn A, Owen CG, et al. Predicting Adult Obesity From Childhood Obesity: A Systematic Review and Meta-analysis. Obes Rev 2016; 17: 95-107. doi: 10.1111/obr.12334

9. Ward Z, Long M, Resch S, et al. Simulation of Growth Trajectories of Childhood Obesity into Adulthood. N Engl J Med 2017; 377: 2145-2153. doi: 10.1056/NEJMoa1703860

10. Pulgarón E. Childhood Obesity: A Review of Increased Risk for Physical and Psychological Comorbidities. Clin Ther 2013; 35: A18-A32. doi: 10.1016/j.clinthera.2012.12.014

11. Farhat T, lannotti R, Simons-Morton B. Overweight, Obesity, Youth, and Health-Risk Behaviors. Am J Prevent Med 2010; 38: 258-267. doi: 10.1016/j.amepre.2009.10.038

12. Kaufman F, Shaw J. Type 2 diabetes in youth: rates, antecedents, treatment, problems and prevention. Pediatric Diabetes 2007; 8: 4-6. doi: 10.1111/j.1399-5448.2007.00327.x

13. Arslanian S, Kim J, Nasr A, et al. Insulin Sensitivity Across the Lifespan from Obese Adolescents to Obese Adults with Impaired glucose tolerance: Who is worse off? Pediatric Diabetes 2017; 19: 205-211. doi: 10.1111/pedi.12562

14. Tilg H, Moschen AR. Inflammatory Mechanisms in the Regulation of Insulin Resistance. Mol Med 2008; 14: 222-231. doi: 10.2119/200700119.tilg

15. Schwimmer JB, Newton KP, Awai HI, et al. Paediatric gastroenterology evaluation of overweight and obese children referred from primary care for suspected non-alcoholic fatty liver disease. Aliment Pharmacol Ther 2013; 38: 1267-1277. doi: 10.1111/apt.12518
16. Pais R, Barritt AS, Calmus Y, et al. NAFLD and Liver Transplantation: Current Burden and Expected Challenges. J Hepatol 2016; 65: 1245-1257. doi: 10.1016/j.jhep.2016.07.033

17. Licenziati MR, Valerio G, Vetrani I, et al. Altered Thyroid Function and Structure in Children and Adolescents Who Are Overweight and Obese: Reversal after Weight Loss. J Clin Endocrinol Metab 2019; 104: 2757-2765. doi: 10.1210/jc.2018-02399

18. Kaaks R. Nutrition, Insulin, IGF-1 Metabolism and Cancer Risk: A Summary of Epidemiological Evidence. Novartis Found Symp 2008; 262: 247-260. doi: 10.1002/0470869976.ch16

19. Chen YC, Dong GH, Lin KC, et al. Gender Difference of Childhood Overweight and Obesity in Predicting the Risk of Incident Asthma: A systematic Review and Meta-analysis. Obes Rev 2013; 14: 222231. doi: 10.1111/j.1467-789X.2012.01055.x

20. Versini M, Jeandel P, Rosenthal E, et al. Obesity in Autoimmune Diseases: Not a Passive Bystander. Autoimmun Rev 2014; 13 : 981-1000. doi: 10.1016/j.autrev.2014.07.001

21. Umano GR, Pistone C, Tondina E, et al. Pediatric Obesity and the Immune System. Front Pediatr 2019; 7: 1-9. doi: 10.3389/ fped.2019.00487

22. Warschburger P, Kroller K. Maternal Perception of Weight Status and Health Risks Associated with Obesity in Children. Pediatrics 2009; 124: e60-e68. doi: 10.1542/peds.2008-1845

23. Etelson D, Brand D, Patrick P, et al. Childhood Obesity: Do Parents Recognize This Health Risk? Obesity Research 2003; 11: 13621368. doi: 10.1038/oby.2003.184

24. Wright D, Lozano P, Dawson-Hahn E, et al. Parental Predictions and Perceptions Regarding Long-Term Childhood Obesity-Related Health Risks. Acad Pediatr 2016; 16: 475-481. doi: 10.1016/j. acap.2016.02.007.

25. Vittrup B, McClure D. Barriers to childhood obesity prevention: Parental knowledge and attitudes. Pediatric Nursing 2018; 44: 81-94.

26. Crawford D, Timperio A, Telford A, et al. Parental Concerns about Childhood Obesity and the Strategies Employed to Prevent Unhealthy Weight Gain in Children. Public Health Nutrition 2006; 9: 889-895. doi: 10.1017/PHN2005917

27. Myśliwiec M, Myśliwczyk D, Wołoszyn-Durkiewicz A. Metabolic consequences of improper nutrition of children and youth. Przegl Pediatr 2019.

28. Robinson E, Daly M, Sutin A. Examination of parental knowledge of child weight status and associated potential health risks. Int J Obes (Lond) 2020; 44: 1928-1935. doi: 10.1038/s41366-0200587-6.

29. Drewa A, Zorena K. Prevention of overweight and obesity in children and adolescents in European countries. Pediatric Endocrinology Diabetes and Metabolism 017; 23: 152-158. doi: 10.18544/ PEDM-23.03.0087

30. Woods TM, Nies MA. Examination of parental knowledge of child weight status and associated potential health risks. J Educ Health Promot 2020; 9: 76. doi: 10.4103/jehp.jehp_43_19

31. Zgliczyński W. Nadwaga i otyłość w Polsce. Infos BAS 2018; 4: 1-3. 